»Schwarz auf weiß«

Maske und Schrift des heraldischen Ornaments 


\section{Waltraud Gut}

\section{»Schwarz auf weiß« \\ Maske und Schrift \\ des heraldischen Ornaments}

Verlag J. B. Metzler

Stuttgart · Weimar 
Die Deutsche Bibliothek - CIP-Einheitsaufnahme

\section{Gut, Waltraud:}

»Schwarz auf weiß«. Maske und Schrift des heraldischen Ornaments.

- Stuttgart ; Weimar : Metzler, 2000

Zugl.: Konstanz, Univ., Diss. 1998

ISBN 978-3-476-45246-7

ISBN 978-3-476-02747-4 (eBook)

DOI 10.1007/978-3-476-02747-4

Dieses Werk einschließlich aller seiner Teile ist urheberrechtlich geschützt. Jede Verwertung außerhalb der engen Grenzen des Urheberrechtsgesetzes ist ohne Zustimmung des Verlages unzulässig und strafbar. Das gilt insbesondere für Vervielfältigungen, Übersetzungen, Mikroverfilmungen und die Einspeicherung und Verarbeitung in elektronischen Systemen.

M \& P Schriftenreihe für Wissenschaft und Forschung

(c) 2000 Springer-Verlag GmbH Deutschland Ursprünglich erschienen bei J.B.Metzlersche Verlagsbuchhandlung und Carl Ernst Poeschel Verlag GmbH in Stuttgart 2000 


\section{Inhaltsübersicht}

1. 0 Einleitung: Diskurs und Metapher des Wappens 7

$\begin{array}{ll}\text { 1. } 1 \text { Das Wappen auf Reisen } & 10\end{array}$

1. 2 Das Wappen des Entdeckers und das Wappen des Anfangs 12

1. 3 Das Wappen als Negativ der Schrift 16

1. 4 Das Wappen als erzählter Körper $\quad 19$

2. 0 Abenteuerliche Mobilität 21

2. 1 Zur Heterotopie des Mittelalters 21

2. 2 Abenteuerliche Rüstungen und höfische Feste 26

2. 3 Vagabundierende Aristokraten 38

2. 4 Ritter und Rittertum 46

3. 0 Im Museum der Geschlechter 64

3. 1 Das Wappen der Sachkultur 64

3. 2 Das Wappen des Namens $\quad 75$

4. 0 Ornamente des Kulturbegriffs $\quad 80$

4. 1 Ornament und Gegen-Ordnung $\quad 80$

4. 2 Ornament und Textur 85

4. 3 Ornamentlektüren 92

5.0 Ornament und Schrift 110

5. 1 Der Herold als Agent der Transcodierung 110

5. 2 Der Begriff der Repräsentation und seine Medien 119

5. 3 Repräsentation und Appräsentation 130

5. 4 Der Herold im Feld der höfischen Kommunikation 135

5. 5 Heraldik als entzifferte Ornamentik 146

5. 6 Groteske Heraldik 153 
6. 0 Ornament und Körper 166

6. 1 Wappen und Körper 166

6. 2 Wappenstil und Schneiderkunst 176

6. 3 Der Körper als Text 183

6. 4 Ornament der Geste: Symmetrisches und Asymmetrisches 191

6. 5 Die Fahrenden: die hybride Maske der Mimesis 209

6. 6 Das Geteilte und das Ganze 217

6. 7 Montage und Ensemble 229

7. 0 Ornament und Text 245

7. 1 Segmentieren und Skelettieren 245

7. 2 Zerteilen und Zusammenfügen 258

7. 3 Poetologische Symmetrien im höfischen Roman 271

7. 4 Masken des Schreibens 281

7. 5 Schreibstuben 293

$\begin{array}{ll}\text { 8. } 0 \text { Zusammenfassung } & 299\end{array}$

Anhang

$\begin{array}{ll}\text { A Bildtafeln } & 305\end{array}$

B Bildnachweis 338

C Literaturnachweis $\quad 340$ 